\title{
Accessibility Based on User Perception of Rehabilitation Center for People with Physical Disabilities (BRSPDF) Wirajaya Makassar
}

\author{
Mutmainna Mansyur ${ }^{\mathrm{a}, *}$, Triyatni Martosenjoyo ${ }^{\mathrm{b}}$, Edward Syarif ${ }^{\mathrm{c}}$ \\ ${ }^{a}$ Architecture Department, Engineering Faculty, Hasanuddin University. Email:mutmainnamansyur@yahoo.co.id \\ ${ }^{b}$ Architecture Department, Engineering Faculty, Hasanuddin University. Email:triyatni@gmail.com \\ ${ }^{\mathrm{c}}$ Architecture Department, Engineering Faculty, Hasanuddin University. Email:edosyarif@yahoo.com
}

\begin{abstract}
In planning a building and environment, not only design that needs to be considered but also accessibility. Accessibility that can be accessed by everyone for the creation of equal opportunities. In designing, the perception of the environment is important, The Social Rehabilitation Center for People with Physical Disabilities (BRSPDF) Wirajaya is a rehabilitation center for people with physical disabilities to acquire skills so that they can work independently. So accessibility is very important in supporting activities in Rehabilitation Center. Based on this, this study aims to analyze the level of conformity of accessibility elements to the principle of facilities and accessibility. In this research the method used is the survey method and use the questionnaire as a research instrument, a type of quantitative descriptive research.. The results showed that the level of conformity of accessibility elements to safety is $74.1 \%$, convenience $79.5 \%$, usability $71.8 \%$, and independence $64.1 \%$.
\end{abstract}

Keywords: Accessibility; people with disabilities; perception; universal design

\section{Introduction}

In planning a building and environment, not only the design that needs to be considered but one of them is accessibility Accessibility is not only intended for normal people, but also for people with disabilities so that there is no architectural discrimination for the creation of equal rights and opportunities. Equal opportunity is a situation that provides opportunities and/or provides access to people with Disabilities to channel potential in all aspects of state and community organizing [1] and facilitated for people with disabilities in providing accessibility.

Accessibility is the convenience provided for people with disabilities to realize equal opportunities [1]. The law also explains the similarity of opportunities where people with disabilities are given opportunities in providing access in all aspects to channel their potential.

The phenomenon that occurs today, people with disabilities still do not fully get equal rights and equality in terms of facilities and accessibility, especially in public spaces. Along with the rapid development of the city of Makassar, it is still not fully implemented the concept of universal design where public spaces should be accessible

${ }^{*}$ Corresponding author. Tel.: +6285-241-843-494

Poros Malino Street Km.6, Gowa

Sulawesi Selatan, Indonesia 92171 from children, adults, seniors and people with disabilities so that there is no discrimination in public spaces.

The similarity of opportunities is not only in the social aspect, but also in the economic aspect. The government has opened up employment opportunities for people with disabilities, both in government and non-governmental environments such as jobs that require skills. One of the government's efforts in creating equal opportunities in terms of skills is by providing a place of social rehabilitation. Through the ministry of social affairs, the government has provided halls such as the Wirajaya Makassar Social Rehabilitation Center for People with Physical Disabilities (BRSPDF) to accommodate the skills of people with physical disabilities.

For the creation of rehabilitation patterns in BRSPDF Wirajaya Makassar, it is considered necessary to pay attention to the supporting factors of activities contained in it. One of the supporting factors of the activity is accessibility that can be accessed by people with disabilities. Accessibility rights are clearly regulated in Law No. 8 of 2016, where it is mentioned that accessibility rights for persons with disabilities include obtaining accessibility to utilize public facilities and obtaining decent accommodation as a form of accessibility for individuals.

The existing conditions in BRSPDF Wirajaya apply some accessibility including signs and markers, ramps, guide lanes, pedestrian paths but have not reached the 
entire hall area. Although BRSPDF Wirajaya is specialized for people with physical disabilities, but regional planning must apply the concept of universal design, where the design of the place is not only for people with physical disabilities who can access but also other people with disabilities. The principle of universal design is very likely to be applied to create facilities for people with disabilities because the segmentation of this design is not limited to age, gender, normal or disability etc. [2].

From some of these conditions, it is considered necessary to conduct research on existing accessibility in order to provide recommendations for effective and accessible accessibility design directives both for the hall and for similar buildings.

\section{Literature Review}

\subsection{Accessibility}

Accessibility is the convenience that is provided for everyone to realize equal opportunities in all aspects of their lives and livelihoods. Accessibility is a part of people's lives, so accessibility is essential for people with disabilities [3].

From the above definitions, it can be concluded that accessibility is an ease that is provided to be accessible to all people including people with disabilities without discrimination so as to realize equal opportunities in various aspects of life. Accessibility includes the following principles [4].

a. Safety, i.e. everyone can reach all places or buildings that are general in an environment.

b. Uses, namely everyone should be able to use a place or building that is general in an environment.

c. Safety, every building that is general in a waking environment, must pay attention to safety for everyone.

d. Independence, everyone must be able to reach in and use all places or buildings that are general in an environment without the need for the help of others.

\subsection{People with disabilities}

According to The Great Dictionary of Indonesian, people with disabilities are defined as people who bear (suffer) something. While disability is an Indonesian word derived from the English word disability (plural: disabilities) which means disabled or inability [5]. Disability is generally defined as a condition in which a person experiences physical, mental, intellectual and sensory deficiencies or imperfections [6]. Disability is generally interpreted as a condition in which a person experiencing deficiencies or imperfections in terms of physical, mental, intellectual and sensory [7].

People with disabilities are any person who has longterm physical, intellectual, mental and/or sensory disabilities who in interacting with the environment may experience obstacles and difficulties in participating fully and effectively with other citizens based on equal rights [8]. From several definitions of persons with disabilities, it can be concluded that people with disabilities are people who have limitations both physically and mentally and have difficulty in some aspects of life.

\subsection{Universal design}

Universal Design is a design concept intended for everyone regardless of difference [9]. According to Makassar City Regional Regulation No. 6 of 2013 universal design is a product design, environment, programs and services that can be used by everyone to the maximum extent possible, without the need for an adaptation or special design including aids for certain groups of people with disabilities at the time of need [10]. Any public space required to provide an inclusif design in order to accommodate a variety of different needs because everyone have the same human rights [7].

Universal Design aims to facilitate everyone's life through product creation, built environment and communication to be used as much as possible and provide added value for everyone of all ages and abilities [8].

From some of the above definitions, it can be concluded that universal design is a design that can be used by everyone ranging from children, the elderly and people with disabilities. The main principles of Universal Design, according to Folente Story in the Universal Design Handbook [11].

a. Can be used by anyone (Equitable Use).

b. Flexibility in Use

c. Simple and Intuitive Use

d. Perceptible Information

e. Tolerance for Error

f. Low Physical Effort

g. Size and Space for Approach and Use

\subsection{Perception}

Etymologically, perception comes from the Latin percipere, which means to receive or take. Perception is a process within a human being that allows it to have the ability to select, organize, and interpret stimuli from the surrounding environment, and that process affects individual behavior [12]. Humans have different characteristics and perceptions based on age children, adolescents and adults [13]. Therefore, perception is a person's response in receiving something from the environment.

There are several theories about perception. In general, some experts agree that perception is influenced by factors such as experience, knowledge background, physical background, social and cultural [14].

a. Environmental Perception

Environmental perception is the interpretation of an individual's setting, based on the individual's cultural background, reason and experience [15].

b. Perceived Environment

Perceived Environment is a product or form of environmental perception of a person or group of people [15].

\section{Research Methods}

\subsection{Research type}

This type of research is descriptive quantitative. The research was conducted by describing the conditions in BRSPDF Wirajaya Makassar. The method in this study uses survey method. The research started from observation in the field and measurement, then adjusted to Permen 
PUPR No. 14/PRT/M/2017. In addition, the distribution of questionnaires intended for individu, in this case the individual in question is the beneficiary in BRSPDF Wirajaya Makassar. The population in this study was 39 people, 31 men and 8 women. In this study using sampling techniques, namely saturated sampling for the distribution of questionnaires because people with physical disabilities who are in BRSPDF Wirajaya Makassar are few in number. As for the interview, use incidental sampling, which represents one of the types of disabilities encountered at the time.

\subsection{Research data source}

The data sources in this study are primary and secondary data:

a. Primary Data

Primary data in the form of data collected by researchers, directly from the first source or place of research object is conducted through observation method and interview / interview. The data collected is in the form of documentation of accessibility conditions at BRSPDF Wirajaya Makassar, the results of questionnaires that have been shared and the results of interviews in person.

b. Secondary data

Secondary data in the form of publications of journals, books or other relevant reading sources.

\subsection{Research instruments}

In connection with the research method used, it takes several research instruments to support this research. Research instruments are tools used by researchers in retrieving data and as a means of supporting the research process, research instruments in this research include:

a. Camera

Camera used to document the condition of accessibility elements in BRSPDF Wirajaya Makassar.

b. Quetionnaire

The questionnaire contains several questions related to user convenience.

c. Meters

Meters are used in measuring accessibility elements such as ramps, guide paths, pedestrian paths, as well as the dimensions of signs and markers.

d. SPSS software

SPSS software is used to process questionnaire data to measure the validity of data. SPSS software used is SPSS 16.0

\subsection{Location}

Research location of Social Rehabilitation Center for People with Physical Disabilities (BRSPDF) Wirajaya Makassar located at Jalan A.P Pettarani Km.4 Subdistrict Tamanuang Panakkukang Makassar Province South Sulawesi. The research was conducted in the part of the hall that is often used by beneficiaries, namely in the dormitories, skill buildings, sports halls, halls, mosques, and workshops. The area is an area often used by beneficiaries so that researchers can meet directly for interviews and questionnaires. As for the location of the research can be seen in Fig. 1.

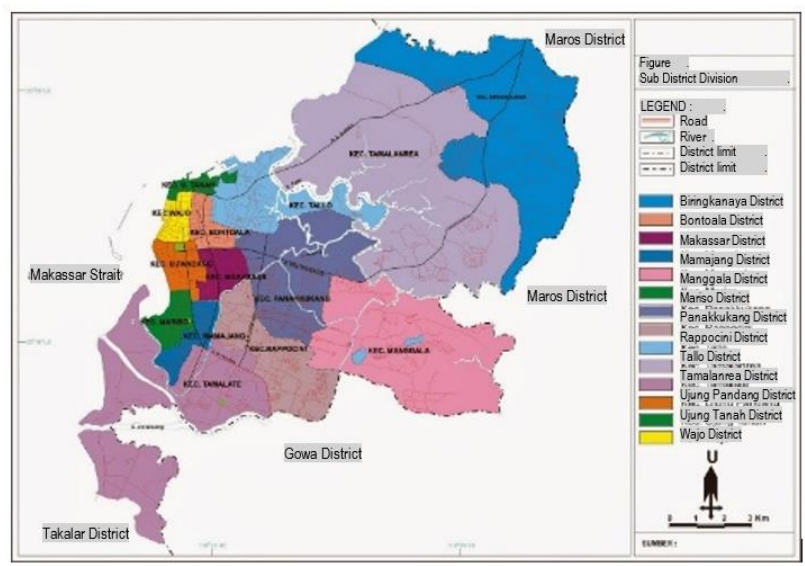

(a)

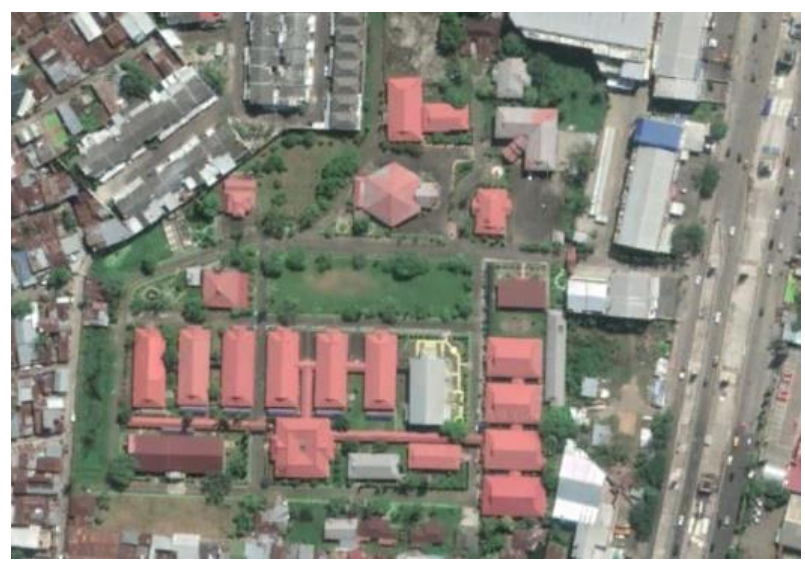

(b)

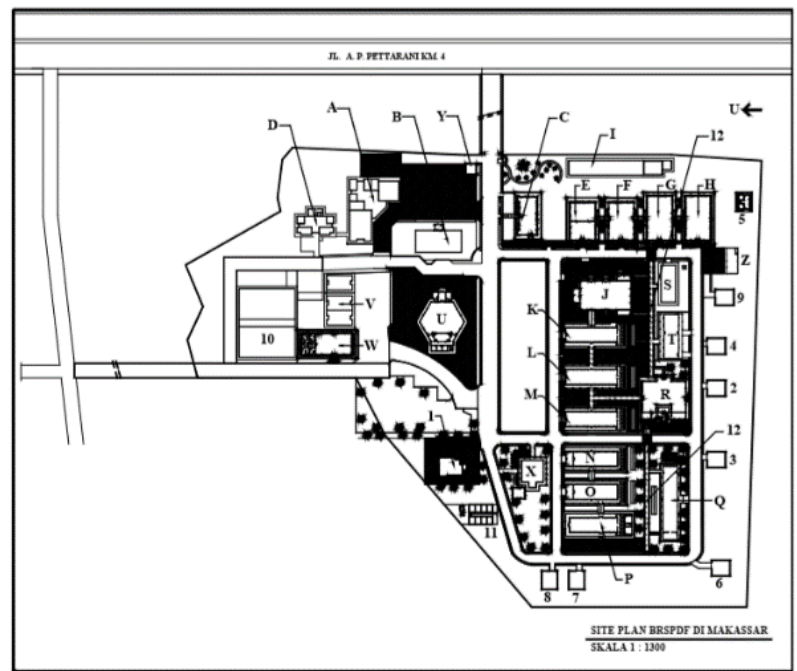

(c)

Figure 1. Research location (a) Makassar City Map, (b) BRSPDF Wirajaya Makassar location map, (c) BRSPDF Wirajaya Makassar floor plan

\subsection{Research variables}

The variables in this study were distinguished into two namely free variables and bound variables. In this study the bound variables were accessibility and user perception. free variables are signs and markers, ramps, guide paths, pedestrian paths, safety, convenience, usefulness, and independence. 


\section{Validity and Reliability Test}

In quantitative research, to obtain valid, reliabel and objective data, the research was conducted using valid and reliabel instruments, conducted on samples close to population numbers and data collection and analysis was carried out in the right way [3]. Analysis of user perception of accessibility is measured by using SPSS which is a test of validity and reliability.

\subsection{Validity}

To perform a validity test using the likert scale, all questions answered from respondents were weighted, strongly agreed $=4$, agreed $=3$, disagreed $=2$ and strongly disagreed $=1$.

Number of questions 12, number of respondents 39 people. All questions are said to be valid because $r$ count is greater than $r$ table. Where for the number of respondents $n=39$, the value $r$ table is 0.3 .

\subsection{Reliability}

In this study also used reliability test to find out the reliability of questions in the questionnaire. This test is done by comparing cronbach alpha with cronbach alpha provision of at least 0.6. Based on the results of the questionnaire data processing in this study, the value of cronbach alpha obtained was 0.912 greater than cronbach alpha at least 0.6 , so it can be concluded that the questionnaire in this study is reliabel.

\section{Results and Discussion}

\subsection{Sign and markings}

Standard:

a. Embossed or Braille signs that can be read by the blind and other people with disabilities;

b. Signs in the form of images and symbols should be embossed, so that their meaning is easy and fast to interpret;

c. Signs in the form of international signs and symbols;

d. Signs that apply special methods (eg soil pavement differentiation, contrasting colors, etc.);

e. The character and background of the sign must be made of a non-glare material. Characters and symbols must contrast with the background, whether the characters are light over dark, or vice versa;

f. The proportions of letters or characters on a sign must have a width-to-height ratio between $3: 5$ and 1:1, and a letter thickness between 1:5 and 1:10;

g. The height of the letters and numbers on the sign must be measured according to the visibility from where the sign is read.

Field Data:

From the results of observations at BRSPDF Wirajaya Makassar, there are several signs and markings located at several points. Signs in the form of symbols for the blind, wheelchair users, crossing symbols and in the form of writing. The available writing signs are not embossed or braille.

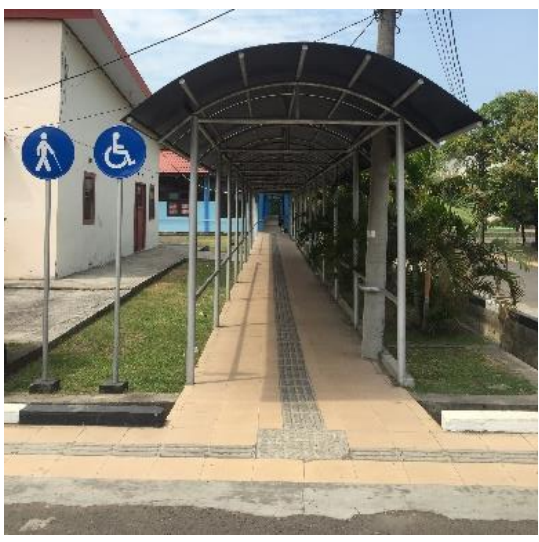

Figure 2. Signs in the form of symbols for the blind and wheelchair users

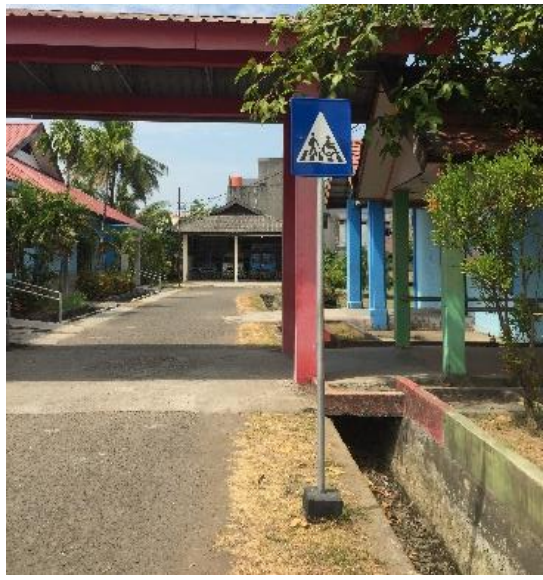

Figure 3. Sign in the form of a crossing symbol

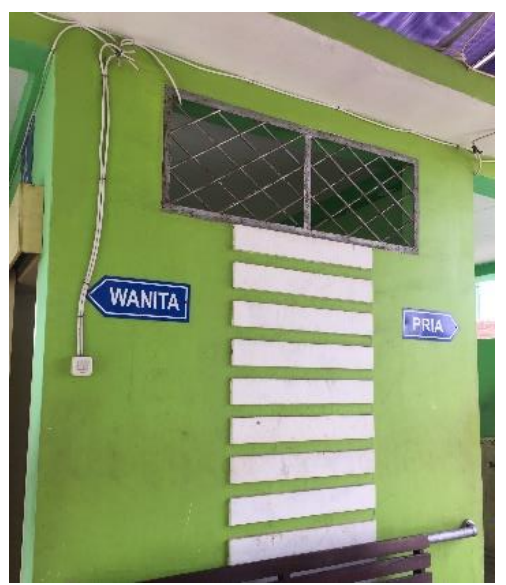

Figure 4. Sign in writing

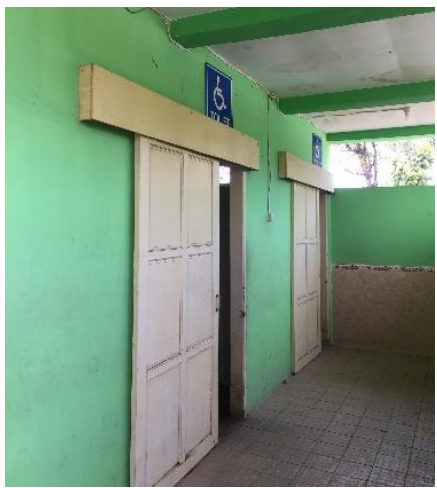

Figure 5. sign in the form of a picture 
Design Instructions:

For people with physical disabilities, signs and markings have met the needs, but for universal design building standards they should be accessible for all people with disabilities without exception. There are no braille signage that can be accessed by persons with sensory disabilities (disabled blind).

\subsection{Ramp}

Standard:

a. The slope of a ramp inside the building must not exceed $7^{\circ}$ while the slope of a ramp outside the building is a maximum of $6^{\circ}$.

b. The minimum width of the ramp is $95 \mathrm{~cm}$ without guard edges, and $120 \mathrm{~cm}$ with guard edges.

c. Flat face/bordes at the beginning or end of a ramp with a minimum size of $160 \mathrm{~cm}$.

d. The width of the ramp/kanstin/low curb safety edge is

e. $10 \mathrm{~cm}$.

f. The vines should be easy to hold with a height of 65 $80 \mathrm{~cm}$.

Field Data:

a. $6^{\circ}$. ramp incline

b. The width of the ramp is $100 \mathrm{~cm}$. Dimensions of ramp $300 \mathrm{~cm} \times 230 \mathrm{~cm}$ and $250 \mathrm{~cm} \times 200 \mathrm{~cm}$.

c. Border $180 \mathrm{~cm}$.

d. Canteen width $20 \mathrm{~cm}$.

e. Vines handle height $80 \mathrm{~cm}$.

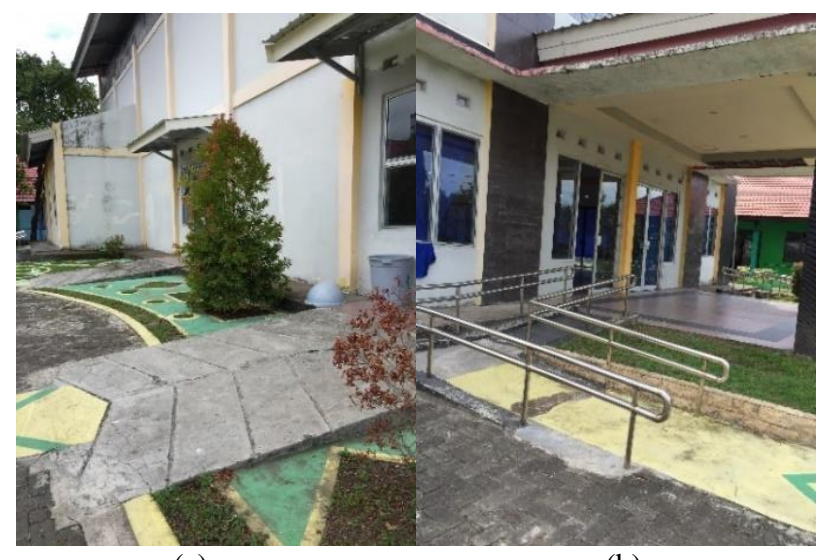

(a)

(b)

Figure 6. (a) Ramp next to the gym, (b) Ramp in front of the gym

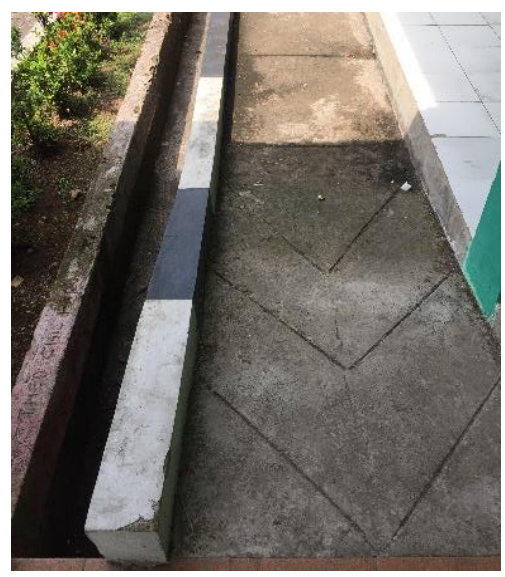

Figure 7. Ramp beside hostel
Design Instructions:

Some of the ramps have met the standard, but there are some rams that do not use safety edges/kanstin and handles like the ram located next to the gym. Therefore, the available ramps need to be equipped with handles and safety edges so that wheelchair users can easily access them.

\subsection{Guide path}

Standard:

a. Striped guiding block

b. Round pattern warning tile

c. Size $30 \times 30 \mathrm{~cm}$

Field Data:

a. Striped guide tiles and round patterned warning tiles. There are tiles with a yellow contrast color.

Design Instructions:

Tiles are only found in certain sections. tiles are not found in all pedestrian paths and corridors. It is recommended that the tiled guide path covers the whole.

\subsection{Pedestrian path}

Standard:

a. The minimum width of the pedestrian path is $120 \mathrm{~cm}$ for one-way lanes and $160 \mathrm{~cm}$ for two directions.

b. The minimum safety edge height is $10 \mathrm{~cm}$ and a width of $15 \mathrm{~cm}$ along the pedestrian path.

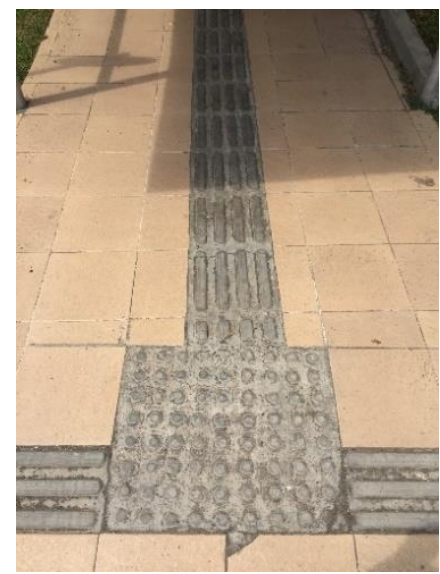

Figure 8. Striped and round pattern tiles

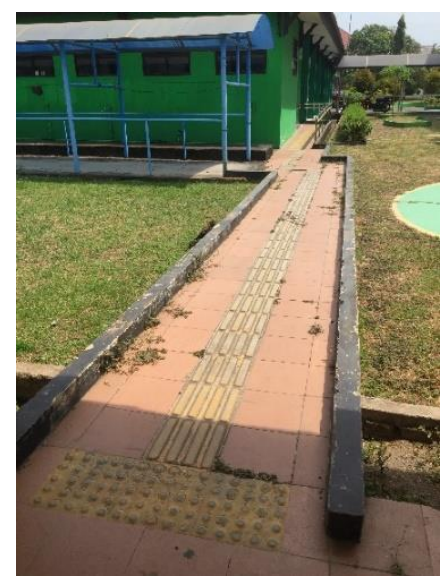

Figure 9. Tiles with contrasting colors 


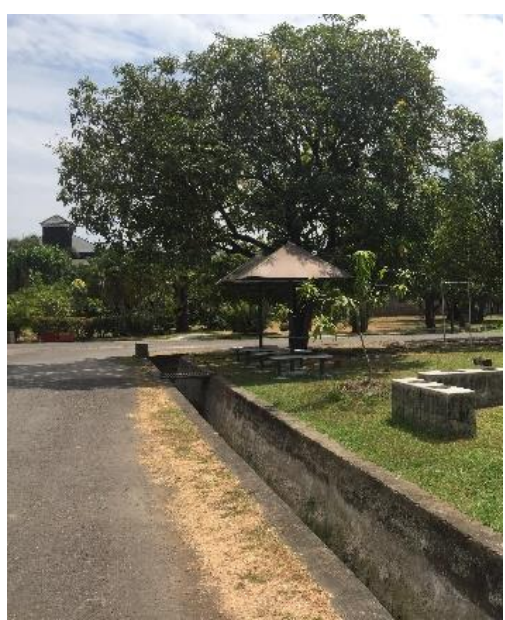

Figure 10. Pedestrian path equipped with seating/resting facilities

Field Data:

a. The width of the pedestrian path is appropriate.

b. The size of the safety edge is high $20 \mathrm{~cm}$ and wide 20 $\mathrm{cm}$.

Design Instructions:

The width of the pedestrian path is in accordance with the standard but not all pedestrian paths are equipped with safety edges for wheelchair users. Completing the pedestrian path by adding a minimum safety edge of 10 $\mathrm{cm}$ and a width of $15 \mathrm{~cm}$ along the pedestrian path.

\subsection{Safety}

Safety variables to measure the user's perception of the height, lighting and texture of accessibility elements.

Based on the Table 1, the accessibility safety principles include height, lighting, textures for signs and markers, ramps, guide paths and pedestrian paths.

a. Signs and markers

For the height of signs and markers are appropriate, respondents answered agreed with a percentage of $66.7 \%$, for lighting signs and markers as much as $48.7 \%$, and the texture of signs and markers $38.5 \%$.

b. Ramp

For ramp height is appropriate, respondents answered agreed with a percentage of $74.4 \%$, for ramp lighting as much as $41.0 \%$, and ramp texture of $66.7 \%$.

c. Guide Path

For the appropriate tile height, respondents agreed with a percentage of $56.4 \%$, for guide path lighting as much as $66.7 \%$, and guide path texture of $74.4 \%$.

d. Pedestrian Path

For the height of the rambat handle is appropriate, respondents answered agreed with a percentage of $74.4 \%$, for pedestrian lane lighting as much as $71.8 \%$, and pedestrian lane texture of $61.5 \%$.

\subsection{Facilities}

Variable ease to measure user perception of the location, achievement and understanding of beneficiaries in accessing accessibility elements.

Based on Table 1, the principles of accessibility include location, achievement, easy to understand for signs and markers, ramps, guide and pedestrian paths.
Table 1 . Accessibility safety results and percentages

\begin{tabular}{|c|c|c|c|}
\hline Questions & $\begin{array}{c}\text { Respondent's } \\
\text { Answer }\end{array}$ & Frequency & Percentage \\
\hline \multirow{5}{*}{$\begin{array}{l}\text { Height of signs and } \\
\text { markers }\end{array}$} & $\mathrm{SS}$ & 7 & 17.9 \\
\hline & $\mathrm{S}$ & 26 & 66.7 \\
\hline & TS & 5 & 12.8 \\
\hline & STS & 1 & 2.6 \\
\hline & SS & 3 & 7.7 \\
\hline \multirow{4}{*}{$\begin{array}{l}\text { Lighting signs and } \\
\text { markers }\end{array}$} & $\mathrm{S}$ & 19 & 48.7 \\
\hline & $\mathrm{TS}$ & 14 & 35.9 \\
\hline & STS & 3 & 7.7 \\
\hline & SS & 4 & 10.3 \\
\hline \multirow{3}{*}{$\begin{array}{c}\text { Texture of signs and } \\
\text { markers }\end{array}$} & $\mathrm{S}$ & 15 & 38.5 \\
\hline & $\mathrm{TS}$ & 12 & 30.8 \\
\hline & STS & 8 & 20.5 \\
\hline \multirow{5}{*}{ Ramp height } & SS & 8 & 20.5 \\
\hline & $\mathrm{S}$ & 29 & 74.4 \\
\hline & $\mathrm{TS}$ & 2 & 5.1 \\
\hline & STS & - & - \\
\hline & SS & 11 & 28.2 \\
\hline \multirow{4}{*}{ Ramp lighting } & S & 16 & 41.0 \\
\hline & $\mathrm{TS}$ & 9 & 23.1 \\
\hline & STS & 3 & 7.7 \\
\hline & SS & 7 & 17.9 \\
\hline \multirow{4}{*}{ Ramp texture } & $\mathrm{S}$ & 26 & 66.7 \\
\hline & $\mathrm{TS}$ & 5 & 12.8 \\
\hline & STS & 1 & 2.6 \\
\hline & SS & 11 & 28.2 \\
\hline \multirow{4}{*}{ Tile height } & $\mathrm{S}$ & 22 & 56.4 \\
\hline & $\mathrm{TS}$ & 6 & 15.4 \\
\hline & STS & - & - \\
\hline & SS & 12 & 30.8 \\
\hline \multirow{4}{*}{ Guide path lighting } & $\mathrm{S}$ & 26 & 66.7 \\
\hline & TS & 1 & 2.6 \\
\hline & STS & - & - \\
\hline & $\mathrm{SS}$ & 8 & 20.5 \\
\hline \multirow{4}{*}{ Guide Path Texture } & $\mathrm{S}$ & 29 & 74.4 \\
\hline & $\mathrm{TS}$ & 2 & 5.1 \\
\hline & STS & - & - \\
\hline & SS & 8 & 20.5 \\
\hline \multirow{4}{*}{$\begin{array}{c}\text { Height of propagate } \\
\text { handle }\end{array}$} & $\mathrm{S}$ & 29 & 74.4 \\
\hline & $\mathrm{TS}$ & 2 & 5.1 \\
\hline & STS & - & - \\
\hline & SS & 9 & 23.1 \\
\hline \multirow{3}{*}{$\begin{array}{l}\text { Pedestrian path } \\
\text { lighting }\end{array}$} & $\mathrm{S}$ & 28 & 71.8 \\
\hline & $\mathrm{TS}$ & 2 & 5.1 \\
\hline & STS & - & - \\
\hline \multirow{4}{*}{$\begin{array}{c}\text { Texture of pedestrian } \\
\text { paths }\end{array}$} & SS & 7 & 17.9 \\
\hline & $\mathrm{S}$ & 24 & 61.5 \\
\hline & $\mathrm{TS}$ & 8 & 20.5 \\
\hline & STS & - & - \\
\hline
\end{tabular}

a. Sign and markers

For the location of signs and markers respondents answered agreed with a percentage of $61.5 \%$, for the achievement of signs and markers as much as $79.5 \%$, and signs and markers easy to understand $48.7 \%$.

b. Ramp

For the ramp location respondents answered agreed with a percentage of $79.5 \%$, for the achievement of ramps as much as 56.4\%, and easy-to-understand ramps of $69.2 \%$. 
Table 2. Accessibility facilities results and percentages

\begin{tabular}{|c|c|c|c|}
\hline Questions & $\begin{array}{l}\text { Respondent's } \\
\text { Answer }\end{array}$ & Frequency & Percentage \\
\hline \multirow{4}{*}{$\begin{array}{l}\text { Location of signs } \\
\text { and markers }\end{array}$} & SS & 14 & 35.9 \\
\hline & S & 24 & 61.5 \\
\hline & TS & 1 & 2.6 \\
\hline & STS & - & - \\
\hline \multirow{4}{*}{$\begin{array}{l}\text { Signs and markers } \\
\text { are easy to find }\end{array}$} & SS & 6 & 15.4 \\
\hline & S & 31 & 79.5 \\
\hline & TS & 1 & 2.6 \\
\hline & STS & 1 & 2.6 \\
\hline \multirow{4}{*}{$\begin{array}{l}\text { Signs and markers } \\
\text { are easy to } \\
\text { understand }\end{array}$} & SS & 18 & 46.2 \\
\hline & S & 19 & 48.7 \\
\hline & TS & 2 & 5.1 \\
\hline & STS & - & - \\
\hline \multirow{4}{*}{ Ramp location } & SS & 6 & 15.4 \\
\hline & S & 31 & 79.5 \\
\hline & TS & 1 & 2.6 \\
\hline & STS & 1 & 2.6 \\
\hline \multirow{4}{*}{$\begin{array}{l}\text { Ramp is easy to } \\
\text { reach }\end{array}$} & SS & 8 & 20.5 \\
\hline & S & 22 & 56.4 \\
\hline & TS & 9 & 23.1 \\
\hline & STS & - & - \\
\hline \multirow{5}{*}{$\begin{array}{c}\text { Ramp is easy to } \\
\text { understand }\end{array}$} & SS & 10 & 25.6 \\
\hline & S & 27 & 69.2 \\
\hline & $\mathrm{TS}$ & 1 & 2.6 \\
\hline & STS & 1 & 2.6 \\
\hline & SS & 9 & 23.1 \\
\hline \multirow{3}{*}{ Guide Path Location } & S & 24 & 61.5 \\
\hline & $\mathrm{TS}$ & 6 & 15.4 \\
\hline & STS & - & - \\
\hline \multirow{4}{*}{$\begin{array}{l}\text { Guide path is easy to } \\
\text { reach }\end{array}$} & SS & 6 & 15.4 \\
\hline & S & 26 & 66.7 \\
\hline & $\mathrm{TS}$ & 7 & 17.9 \\
\hline & STS & - & - \\
\hline \multirow{4}{*}{$\begin{array}{l}\text { Easy-to-understand } \\
\text { guide path }\end{array}$} & SS & 17 & 43.6 \\
\hline & S & 16 & 41.0 \\
\hline & $\mathrm{TS}$ & 6 & 15.4 \\
\hline & STS & - & - \\
\hline \multirow{4}{*}{$\begin{array}{l}\text { Pedestrian Line } \\
\text { Location }\end{array}$} & SS & 9 & 23.1 \\
\hline & S & 28 & 71.8 \\
\hline & $\mathrm{TS}$ & 2 & 5.1 \\
\hline & STS & - & - \\
\hline \multirow{4}{*}{$\begin{array}{l}\text { Pedestrian paths are } \\
\text { easy to reach }\end{array}$} & SS & 6 & 15.4 \\
\hline & S & 26 & 66.7 \\
\hline & $\mathrm{TS}$ & 7 & 17.9 \\
\hline & STS & - & - \\
\hline \multirow{4}{*}{$\begin{array}{l}\text { Easy-to-understand } \\
\text { pedestrian path }\end{array}$} & SS & 5 & 12.8 \\
\hline & S & 19 & 48.7 \\
\hline & TS & 13 & 33.3 \\
\hline & STS & 2 & 5.1 \\
\hline
\end{tabular}

c. Guide Path

For the location of the guide path respondents answered agreed with a percentage of $61.5 \%$, for the achievement of the guide path as much as $66.7 \%$, and the guide path is easy to understand $41.0 \%$.

d. Pedestrian path

For the location of pedestrian lanes respondents answered agreed with a percentage of $71.8 \%$, for the achievement of pedestrian lanes as much as $66.7 \%$, and easy-to-understand pedestrian lanes $48.7 \%$.

\subsection{Uses}

Usability variable to measure user perception of accessibility element functionality.

Based on Table 3, the principles of accessibility use include the function of signs and markers, ramp function, guide path function and pedestrian path function. For sign and marker function reseponden answered $56.4 \%$, ramp function $48.7 \%$, guide path function $71.8 \%$, and pedestrian path function $48.7 \%$.

Tabel 3. Accessibility uses results and percentages

\begin{tabular}{cccc}
\hline Questions & $\begin{array}{c}\text { Respondent's } \\
\text { Answer }\end{array}$ & Frequency & Percentage \\
\hline $\begin{array}{c}\text { Signs and markers } \\
\text { functions }\end{array}$ & SS & 7 & 17.9 \\
& TS & 22 & 56.4 \\
Ramp functions & STS & 1 & 23.1 \\
& SS & 5 & 2.6 \\
& TS & 19 & 12.8 \\
Guide path functions & STS & 14 & 48.7 \\
& SS & 4 & 35.9 \\
& TS & 28 & 2.6 \\
Pedestrian path & STS & 6.3 & 71.8 \\
functions & SS & 5 & 15.4 \\
& S & 19 & 2.6 \\
& STS & 14 & 48.7 \\
& & 1 & 35.9 \\
& & & 2.6 \\
\hline
\end{tabular}

Table 4. Results and percentages of independence

\begin{tabular}{cccc}
\hline \multirow{2}{*}{ Questions } & $\begin{array}{c}\text { Respondent's } \\
\text { Answer }\end{array}$ & Frequency & Percentage \\
\hline \multirow{3}{*}{ Confidence Level } & SS & 16 & 41.0 \\
& S & 19 & 48.7 \\
& TS & 3 & 7.7 \\
& STS & 1 & 2.6 \\
Discipline & SS & 11 & 28.2 \\
& S & 21 & 53.8 \\
& TS & 7 & 17.9 \\
& STS & - & - \\
Responsibility & SS & 12 & 30.8 \\
& S & 25 & 64.1 \\
& TS & 2 & 5.1 \\
& STS & - & - \\
\hline
\end{tabular}




\subsection{Independence}

Independence variables to measure a user's perseption against a degree of confidence. user discipline and responsibility.

Based on Table 4, the principles of accessibility independence include self-reliance, discipline and responsibility. For the independence of respondents answered $48.7 \%$, discipline came on time in each activity $53.8 \%$, responsibility can complete each task given $64.1 \%$.

\section{Conclusions and Suggestions}

\subsection{Conclusions}

a. The availability of overall accessibility elements in BRSPDF Wirajaya Makassar has met the needs of people with physical disabilities but does not yet include the overall principles of universal design. BRSPDF Wirajaya provides facilities in accordance with the type of disability received, namely people with physical disabilities.

b. The level of conformity based on the principles of facilities and accessibility include safety, convenience, usefulness and independence as follows.

- For safety variables, the highest percentage of respondents answered agreed $74.4 \%$ for ramp height, guide path texture and propagate handle height.

- For ease variables, the highest percentage of respondents answered agreed $79.5 \%$ for the achievement of signs and markers and ramp location.

- For usability variables, the highest percentage of respondents answered agreed $71.8 \%$ for the guide path function.

- For variable of independence, the highest percentage of respondents answered agreed $64.1 \%$ is the responsibility in completing the task

\subsection{Suggestions}

a. Universal design should be a reference in designing accessibility, so that accessibility can be accessed not only for people with physical disabilities but for all people with disabilities.

b. The guide path that already exists but does not cover the entire building, it is considered necessary to pay attention to the existing guide path so that it is accessible for all people with disabilities.

c. The existing guide path but does not cover the entire building, it is considered necessary to pay attention to the existing guide path so that it can be accessed for all persons with disabilities.

d. Further research is needed on the specific accessibility of indoor space at BRSPDF Wiraya Makassar.

e. The government in providing a hall such as BRSPDF Wirajaya pays attention to accessibility, and one of the references can be used the results of this research

\section{References}

[1] S. Hanrahan, "Persons with Disabilities," 2016

[2] M. F. K. Thezar, "Accessibility of Disabilities in Karebosi Field as a Public Space of Makassar City," 2016.

[3] L. Nuraviva, "Accessibility of Persons with Disabilities to Public Facilities In Surakarta City."

[4] N. Dewang and Leonardo, "Accessibility of public open space for certain community groups study public facilities for people with disabilities in the area of suropati menteng park - central Jakarta," PLANESA J., vol. 1, no. 1, 2010

[5] Great Dictionary of Indonesia. 2018

[6] E. Chandra et al., "Accessibility of People with Physical Disabilities to Work in Cipaisan Subdistrict Of Purwakarta Purwakarta Regency," Sci. J. Policy Soc. Work Serv., vol. 2, no. $1,2020$.

[7] R. M. Harahap et al., "The Influence of Universal Design and Usability in Public Facilities in Universities for Persons with Disabilities," J. Eng. Comput. Sci., vol. 3, no. 2, 2019.

[8] Ministry of Public Works and Public Housing, "Permen PUPR No. 14/PRT/M/2017,” 2017.

[9] I. Pujiyanti, "Implementation of Universal Design in Higher Education Facilities," J. Archit. Plan., vol. 1, no. 2, pp. 223-239, 2018.

[10] Ministry of Law and Justice, "the Fulfillment of The Rights of Persons with Disabilities," 2013.

[11] M. F. Story, "The Universal Design File: Designing for People of All Ages and Abilities," North Carolina State University, 1998.

[12] D. Mulyada, Communication Science An Introduction. Bandung: Teenager Rosdakarya, 2010.

[13] Suharto, S. Deby, and L. Kristanto, "Evaluation of Visitor Perception Against Architectural Elements at the Ten November Struggle Museum," eDIMENSI Archit. J., vol. 7, no. 1, pp. 369$376,2019$.

[14] A. Harisah and Z. Masiming, "Human Perception of Signs, Symbols, and Spatial," SMARTek J., vol. 6, no. 1, pp. 29-43, 2008.

[15] Haryadi and B. Setiawan, Environmental and Behavioral Architecture. Yogyakarta: Project developer of The Center for Environmental Studies. Directorate General of Higher Education Ministry of Education and Culture of the Republic of Indonesia, 1995. 